TEME, г. XLIV, бр. 4, октобар - децембар 2020, стр. 1441-1456

\begin{tabular}{lr}
\hline \hline Претходно саошштење & https://doi.org/10.22190/TEME190715085V \\
Примљено: 15.7 .2019$. & UDK 347.728.1 \\
Ревидирана верзија: 12. 9. 2019. & $334.726(497.11)$ \\
Одобрено за штампу: 1.12 .2020$. &
\end{tabular}

\title{
PROFIT SHIFTING TO EUROPEAN TAX HAVENS: THE CASE OF SUBSIDIARIES OF MULTINATIONAL COMPANIES IN SERBIA ${ }^{a}$
}

\author{
Stefan Vržina \\ University of Kragujevac, Faculty of Economics, Kragujevac, Serbia \\ *stefan.vrzina@kg.ac.rs
}

\begin{abstract}
Due to the presence in a number of countries, multinational companies (MNCs) are in position to register a considerable part of pre-tax profit in countries with a preferential tax regime in order to avoid paying taxes at high rates. In other words, MNCs are able to shift profit from countries with a high tax burden to countries with low tax burden. In this paper, it is examined whether Serbian subsidiaries of MNCs, directly owned by European tax haven entities, more intensively shift profit to tax havens relative to other subsidiaries. A list of tax havens published by Oxfam in 2016 is used. Statistical tests and regression analysis showed that there is no significant difference in profit shifting to tax havens between two mentioned groups of subsidiaries. Therefore, it is possible that MNCs consider Serbia as a country with preferential tax regime due to relatively low statutory and effective corporate income tax rates. However, for the purposes of a detailed analysis, national tax authorities should insist on public disclosure of company tax reports to make tax practices of MNCs more transparent.
\end{abstract}

Key words: profit shifting, corporate income tax, tax havens, tax avoidance, multinational companies.

\section{ПРЕМЕШТАЫЕ ДОБИТКА У ЕВРОПСКЕ ПОРЕСКЕ РАЈЕВЕ: СЛУЧАЈ ФИЛИЈАЛА МУЛТИНАЦИОНАЛНИХ КОМПАНИЈА У СРБИЈИ}

Апстракт

Услед присуства у више држава, мултинационалне компаније (МНК) у позицији су да региструју значајан део добитка пре опорезивања у државама са преференцијалним пореским режимом како би избегле плаћање пореза по високим стопама. Другим речима, МНК могу премештати добитак из држава са високим пореским оп-

${ }^{a}$ This paper is result of the project III 47005 , financed by the Ministry of Education, Science and Technological Development of the Republic of Serbia. 
терећењем у државе са ниским пореским оптерећењем. У овом раду је истражено да ли српске филијале МНК, у директном власништву ентитета из европских пореских рајева, интензивније премештају добитак у пореске рајеве у односу на остале филијале. У раду је коришћена листа пореских рајева коју је објавио Оксфам 2016. године. Статистички тестови и регресиона анализа показали су да не постоји значајна разлика у премештању добитка у пореске рајеве између две поменуте групе филијала. Стога, могуће је да МНК сматрају Србију државом са преференцијалним пореским режимом услед релативно ниске прописане и ефективне стопе пореза на добитак. Ипак, за сврхе детаљније анализе, требало би да националне пореске власти инсистирају на јавном објављивању пореских извештаја компанија како би пореске праксе МНК биле транспарентније.

Кључне речи: премештање добитка, порез на добитак, порески рајеви, избегавање пореза, мултинационалне компаније.

\section{INTRODUCTION}

Profit shifting to tax havens is a research area that has been widely discussed in the past decades, both from the theoretical and practical viewpoints. However, neither national nor supranational efforts to eliminate such corporate practices have been effective so far (Kurdle, 2009). Therefore, profit shifting to tax havens still appears to be an attractive issue. Huizinga \& Laeven (2008) argue that MNCs have many opportunities to shift profit to countries with preferential tax regimes due to high cross-national differences in tax rates.

Unfortunately, there is no unique list of tax havens. A list of tax havens published by Oxfam (2016) is used here as a most recent significant list of tax havens. In addition, Oxfam is a non-government organization, thus a list should be free of any political bias.

Christian \& Schultz (2005) define profit shifting as the recognition of profit as being earned in a country other than its true source. In other words, entities that are part of MNCs organize transactions in the way that artificially shifts profit from high-tax countries to low-tax countries. For the purpose of this paper, $\mathrm{MNC}$ is defined as a company headquartered in one country, but operating in other countries as well (Doupnik, \& Perera, 2012, p. 12). Thus, research captures subsidiaries of those MNCs which operate in a home country and have subsidiaries in at least two foreign countries.

The paper is based on the idea of Fuest \& Riedel (2012), who argue that the presence of tax haven entity in ownership structure of the subsidiary encourages profit shifting. If this assumption holds, then sampled subsidiaries can be divided into two subsamples:

- linked subsidiaries (directly owned by tax haven entities) and

- other subsidiaries (not directly owned by tax haven entities).

The research subject in this paper is profit shifting to tax havens by Serbian subsidiaries of MNCs. Following Jansky \& Kokes (2016), I 
examined profit shifting exclusively to European tax havens. The first research objective is to examine whether the link with tax haven entities through ownership structure impacts profit shifting to tax havens. In other words, the paper examines whether there exist differences in profit shifting intensity between linked and other subsidiaries. The second research objective is to determine a dominant channel of profit shifting to tax havens.

This research contributes to prior (primarily foreign) research on profit shifting to tax havens. In this regard, the research relies on prior research that studied the same issue and implemented similar methodology (for instance Fuest \& Riedel, 2012; Jansky \& Kokes, 2015; Janky \& Kokes, 2016). To the author's knowledge, this is the first empirical research on profit shifting of Serbian subsidiaries. In fact, prior research on profit shifting from developing countries is relatively scarce (Crivelli, de Mooij, \& Keen, 2016). Research results can be of particular interest to the management of MNCs when considering available worldwide tax minimization options, as well as to the national tax authorities during the analysis of the intensity and dominant methods of profit shifting to tax havens.

Beside the introduction, conclusion and appendices, the paper consists of three parts. The first part gives a theoretical and empirical background on the typical profit shifting channels, possibilities for profit shifting measurement and identification of tax havens. Research methodology and research results are given in the second and the third parts of the paper, respectively.

\section{LITERATURE REVIEW}

Due to the presence in a number of countries, MNCs are in the position to organize their operations in a manner that registers the largest part of pre-tax profit in low-tax countries. Contractor (2016) lists numerous mechanisms that MNCs employ to minimize worldwide corporate income tax liabilities. In terms of profit shifting, Schwarz (2009) emphasizes intragroup trade, intragroup borrowing and intragroup royalty payments and license fees as key profit shifting channels. Considering a lot of captive insurance companies registered in tax havens (Hampton, \& Christensen, 2002), it appears that intragroup insurance also represents a remarkable channel of profit shifting to tax havens.

In order to prevent such practices of MNCs, many countries introduced the withholding tax payment parallel with the payment of mentioned transactions. In situations when the direct money transfer between related-party entities in two different countries requires significant withholding tax payment, MNCs organize a conduit entity in third country to avoid the payment of withholding tax (Arel-Bundock, 2017). The conduit entity can be found in the country that has signed double taxation treaties with countries whose residents are original transaction subjects, or in the 
country that does not impose withholding tax payment and has signed double taxation treaty with the country whose resident is the transaction payer.

Many measures of corporate income tax burden and avoidance in the past decades have been developed. One of the most widely used measures is the effective tax rate, dividing corporate income tax burden by some of the accounting results. However, no consensus has been reached in literature about the way of effective tax rate calculation - for example, Lennox, Lisowsky \& Pittman (2012) employ five different types of effective tax rates.

Effective tax rate, as a corporate income tax avoidance measure, has certain shortcomings. Hanlon \& Heitzman (2010) argue that effective tax rate is not a useful tool for tax avoidance analysis when the tax avoidance practice reduces both taxable profit and accounting pre-tax profit (conforming tax avoidance) since effective tax rate captures only the nonconforming tax avoidance effects. Considering the fact that mentioned transactions between subsidiaries and/or subsidiaries and the parent entity can be placed into conforming tax avoidance practices, the effective tax rate cannot be an appropriate measure of corporate income tax avoidance in MNCs and profit shifting to tax havens. Based on the assumption that subsidiaries that shift profit to tax havens have lower profitability and/or higher leverage, Fuest \& Riedel (2012) use the following additional measures of profit shifting:

- relation between pre-tax profit and total assets;

- relation between corporate income tax expense and total assets and

- relation between liabilities and total assets.

The identification of tax havens is not a simple task, although there have been many attempts at making a unique list of tax havens (for example: Hines, \& Rice, 1994; Musalem, \& Errico, 1999; OECD, 2000; Hines, 2010; Oxfam, 2016). In the Republic of Serbia, the most influential is the list of tax havens published in the Rulebook on the list of jurisdictions with preferential tax system (The Official Gazette of the RS, no. 122/12) from 2012. On that list, as European tax havens, the listed are Andorra, Liechtenstein, Monaco and San Marino, as well as British territories Jersey, Guernsey, Gibraltar and the Isle of Man. Conversely, on the list of tax havens published by Oxfam (2016), the Netherlands, Switzerland, the Republic of Ireland, Luxembourg, Cyprus and Jersey figure as the biggest European tax havens. In addition, the list also includes three British Caribbean territories (the Cayman Islands, Bermuda and the British Virgin Islands) and one Dutch Caribbean territory (Curacao).

A number of empirical studies confirm the influence of corporate income tax on MNCs operations. Grubert \& Mutti (1991) and Hines \& Rice (1994) conclude that subsidiaries of MNCs achieve lower profitability in countries with higher tax rates, indicating that MNCs widely employ 
channels of profit shifting to low-tax countries, though Dharmapala (2014) argues that the intensity of profit shifting declined during the last decade.

The findings of Loretz \& Mokkas (2015), who studied European subsidiaries, support the hypothesis that MNCs shift profit between their foreign subsidiaries for tax reasons adding that intragroup borrowing appears to be the key channel of profit shifting. Mittoo \& Zhang (2008) find that Canadian subsidiaries of MNCs have higher leverage than domestic companies. Using theoretical approach, Chowdhry \& Coval (1998) show positive relation between leverage of subsidiary and tax rate in country where subsidiary is registered. Faulkender \& Smith (2016) add that subsidiaries registered in high-tax countries have higher leverage and lower times interest earned ratio. On the other hand, Huizinga, Laeven \& Nicodeme (2008) argue that leverage of subsidiaries is influenced by a string of factors, including tax rate in subsidiary country, tax rate in parent entity country and tax rates in other subsidiaries countries.

Clausing (2003) studied trade prices among related-party entities and find that export prices from the US are lower, while import prices in the US are higher when tax rate in a foreign country is lower than the rate in the USA. Beer \& Loeprick (2015) find that profitability of subsidiaries in OECD countries declines with the rise in tax rate, whereas such a decline is more expressed in subsidiaries with a higher level of intangible assets.

Many papers studied the differences between linked and other subsidiaries. Weichenrieder (2009) finds that the profitability of subsidiaries in Germany rises with the increase in tax rates in a country to which subsidiary is, through ownership structure, directly linked as a result of the reduction in the profit shifting intensity. Buettner \& Wamser (2013) find that intragroup borrowing, as a profit shifting channel, is more used by MNCs with entities in low-tax countries. Dischinger, Knoll \& Riedel (2014) find profit shifting towards the parent entity when tax rate in parent entity country is lower than the tax rate in the subsidiary country.

Fuest \& Riedel (2012) find that subsidiaries of MNCs achieve lower profitability and pay less corporate income tax related to domestic companies, and that linked subsidiaries achieve lower profitability and pay less corporate income tax related to other subsidiaries. Jansky \& Prats (2015) find that linked subsidiaries in India achieve lower profitability and pay less corporate income tax per unit of assets than other subsidiaries.

Jansky \& Kokes (2015) find that linked subsidiaries in the Czech Republic have higher leverage than other subsidiaries. In addition, Jansky \& Kokes (2016) find potential profit shifting from the Czech subsidiaries to Luxembourg and Switzerland through intragroup borrowing, since linked subsidiaries are highly leveraged compared to other subsidiaries. Studying Slovak subsidiaries, Khouri, Elexa, Istok \& Rosova (2019) show that companies with an ownership link to tax havens pay significantly lower taxes compared to other companies. 
In accordance with previous research results, which suggest that linked subsidiaries more intensively shift profit to tax havens related to other subsidiaries, I expect to find that linked subsidiaries achieve lower profitability, have higher leverage and have lower corporate income tax burden per unit of assets than other subsidiaries. Since most profit shifting channels of MNC subsidiaries rely on conforming tax avoidance, I expect to find no difference between linked and other subsidiaries in effective tax rates, as effective tax rate does not capture the effects of conforming tax avoidance.

\section{DATA AND METHODOLOGY}

\section{Research Context}

In general, the profit of subsidiaries of MNCs in Serbia is taxed in the same manner as the profit of other companies. In other words, subsidiaries of MNCs follow the same procedure as other companies in terms of submitting tax balance and tax return. The taxable base (taxable profit or tax loss) is determined in tax balance. The starting point in the tax balance is the pre-tax result (from the income statement), followed by the adjustments of expenses and revenues in line with Corporate Profit Tax Law (The Official Gazette of the RS, no. 113/2017). On the other hand, current income tax expense is determined in tax return. This expense is calculated after the multiplication of taxable profit with statutory tax rate (in Serbia 15\% with proportional tax system from January 1, 2013) and the deduction of available tax benefits (for instance, investment tax incentive or tax loss carryforward).

The specific tax feature of subsidiaries of MNCs may be found in the potential different tax reporting period. Tax reporting period in Serbia is one year and, in general, this period is a calendar year (from January 1 to December 31). However, subsidiaries of MNCs may (and they often do) opt for different financial reporting and the tax reporting period assumed that this period covers twelve months. Subsidiaries of MNCs in Serbia usually choose modified tax reporting periods if their parent company has the reporting period other than the calendar year in the parent country.

Related-party transactions are inherent to the subsidiaries of MNCs, since they are part of the wider multinational economic groups. Therefore, transfer pricing and thin capitalization rules are of great importance for the subsidiaries when calculating the corporate income tax burden. Following the OECD rules, legislation in Serbia allows the five methods of transfer prices calculation: comparable uncontrolled price method, cost plus method, resale price method, transactional net margin method and the profit split method. In addition, thin capitalization rules allow the recognition of interest expenses from related-parties in the tax balance only up to four times the value of the shareholders' equity of the subsidiary. 


\section{Research Methodology}

The research in this paper is empirically oriented and based on the sample of subsidiaries of MNCs that are registered in Serbia. Abstracting other macroeconomic and microeconomic factors, I examine the impact of the existence of tax haven entities in the ownership structure on chosen financial indicators of subsidiaries.

Beside descriptive statistics, I use parametric or non-parametric (depending on the normality of variables distribution) tests of differences between two independent samples and the panel regression analysis. Such methodology has been widely employed in prior research (for example: Jansky, \& Kokes, 2015; Jansky, \& Prats, 2015; Jansky, \& Kokes, 2016).

I use this methodology to examine the statistical significance of differences between linked and other subsidiaries, by variables defined in Table 1. These are variables employed by Fuest \& Riedel (2012), except for the leverage that is measured with two indicators: relation between total liabilities and total assets (debt ratio), and relation between long-term liabilities and total assets (long-term debt ratio). Namely, the shortcomings of debt ratio pertains to the fact that it captures, among other things, liabilities that usually do not require interest payment, such as payroll liabilities, accounts payable to suppliers, etc. Therefore, I also use long-term debt ratio that captures only long-term liabilities, dominated by liabilities that require interest payment, such as long-term borrowings and long-term lease liabilities. I did statistical data processing through econometric software EViews 9, with statistical significance assessed at $10 \%, 5 \%$ and $1 \%$ confidence levels.

Table 1. Variable definition

\begin{tabular}{|c|c|c|}
\hline $\begin{array}{c}\text { Variable } \\
\text { label } \\
\end{array}$ & Variable name & Formula \\
\hline ROA & Return on assets & (Pre-tax profit / Total assets) $\mathrm{x} 100$ \\
\hline DR & Debt ratio & (Total liabilities / Total assets) x 100 \\
\hline LDR & Long-term debt ratio & (Long-term liabilities / Total assets) x 100 \\
\hline $\mathrm{TpA}$ & Tax per unit of assets & (Current income tax expense / Total assets) x 100 \\
\hline ETR & Effective tax rate & (Current income tax expense / Pre-tax profit) x 100 \\
\hline
\end{tabular}

In line with the research subject, the sample comprises subsidiaries fully owned $(100 \%)$ by entities registered in European countries. Since private (unquoted) companies are more involved in profit shifting than public (quoted) companies (Beuselinck, Deloof, \& Vanstraelen, 2015), the sample comprises only subsidiaries registered as limited liability companies. This legal form is the most frequent legal form in Serbia and the legal form in which MNCs mostly organize their operations in Serbia. In order to ensure the reliability of the financial data, the sample encompasses only subsidiaries 
with audited 2016 financial statements. In order to avoid the dilemma about using statutory or consolidated financial data, the sample includes only the subsidiaries that do not have further subsidiaries in Serbia - therefore, I use data from the statutory financial statements. Data on ownership structure and financial data have been retrieved from the Internet presentation of The Serbian Business Registers Agency (www.apr.gov.rs).

The sample consists of 75 subsidiaries from non-financial sectors during the period between 2013 and 2016. Therefore, the sample initially consists of 300 observations. However, I removed five observations due to the lack of financial data. In addition, I also removed over-indebted observations (with DR or LDR higher than 100\%) and observations beyond three standard deviations around the average of ROA and TpA. Therefore, the final research sample represents the unbalanced panel data of 251 observations. For the purposes of effective tax rate analysis, I considered only the observations with positive pre-tax accounting result - there are 205 such observations.

Most subsidiaries are registered in Belgrade (53 subsidiaries), followed by Vojvodina (10 subsidiaries), Šumadija and Western Serbia (7 subsidiaries) and Southern and Eastern Serbia (5 subsidiaries). In addition, most subsidiaries are directly owned by Austrian (18 companies) and Dutch entities (13 companies). If Oxfam (2016) list of tax havens, as a most recent mentioned list of tax havens, is preferred, then 25 subsidiaries (33.33\%) are directly owned by tax haven entities -13 subsidiaries are owned by Dutch entities, 11 subsidiaries are owned by Swiss entities, while 1 subsidiary is owned by a Cypriot entity. On the other hand, not one subsidiary is directly owned by entities incorporated in the Republic of Ireland, Luxembourg, Jersey, three British Caribbean territories (the Cayman Islands, Bermuda and the British Virgin Islands) or one Dutch Caribbean territory (Curacao) mentioned in the employed Oxfam list. Thus, the sample comprises two subsamples: 25 linked and 50 other subsidiaries.

\section{RESULTS AND DISCUSSION}

\section{Descriptive Statistics}

Table 2 presents descriptive statistics for defined variables, both for the whole sample and subsamples. Out of 251 observations, 84 observations refer to linked subsidiaries, while 167 observations refer to other subsidiaries.

Linked subsidiaries, on average, achieve higher ROA than other subsidiaries. There are 40 sampled subsidiaries that achieved pre-tax profit in each observed year and four sampled subsidiaries that recorded pre-tax loss in all four years. Regarding extreme values, two observations have ROA lower than $-20 \%$, while thirteen observations have ROA higher than $20 \%$.

Leverage, measured with DR ratio, is, on average, higher in other subsidiaries than in linked subsidiaries. However, DR median is higher in 
linked subsidiaries. It is interesting to note that in 19 observations DR was higher than $90 \%$, which can be primarily attributed to the relatively low founding capital and high losses of subsidiaries. On the other hand, there are four subsidiaries with DR ratio higher than $100 \%$ in each observed year.

LDR ratio is, on average, higher in linked subsidiaries. However, this conclusion changes if we rely on median results, since both linked and other subsidiaries have null median LDR. In addition, in 151 observations LDR was $0 \%$. Such finding indicates that long-term financing of subsidiaries is primarily done through the owner's equity rather than long-term borrowing.

Table 2. Descriptive statistics

\begin{tabular}{ccrrrrrr}
\hline Variable & $\begin{array}{c}\text { Subsidi- } \\
\text { aries }\end{array}$ & Mean & Median & Min. & Max. & $\begin{array}{c}\text { Standard } \\
\text { deviation }\end{array}$ & Obs. \\
\hline \multirow{2}{*}{ ROA } & Linked & 6.74 & 4.67 & -17.53 & 41.05 & 11.32 & 84 \\
(in \%) & Other & 4.68 & 4.40 & -33.65 & 44.26 & 9.07 & 167 \\
& Pooled & 5.37 & 4.60 & -33.65 & 44.26 & 9.90 & 251 \\
\hline \multirow{2}{*}{ DR } & Linked & 53.60 & 60.30 & 4.45 & 98.12 & 27.82 & 84 \\
(in \%) & Other & 55.56 & 59.63 & 1.06 & 96.77 & 24.03 & 167 \\
& Pooled & 54.94 & 60.02 & 1.06 & 98.12 & 25.32 & 251 \\
\hline \multirow{2}{*}{ LDR } & Linked & 10.63 & 0.00 & 0.00 & 61.36 & 17.58 & 84 \\
(in \%) & Other & 9.74 & 0.00 & 0.00 & 85.96 & 16.98 & 167 \\
& Pooled & 10.04 & 0.00 & 0.00 & 85.96 & 17.15 & 251 \\
\hline \multirow{2}{*}{ TpA } & Linked & 1.36 & 0.69 & 0.00 & 6.68 & 1.69 & 84 \\
(in \%) & Other & 0.78 & 0.34 & 0.00 & 7.43 & 1.16 & 167 \\
& Pooled & 0.98 & 0.45 & 0.00 & 7.43 & 1.38 & 251 \\
\hline \multirow{2}{*}{ ETR } & Linked & 16.83 & 15.68 & 0.00 & 79.68 & 15.95 & 70 \\
(in \%) & Other & 14.07 & 13.29 & 0.00 & 95.40 & 15.67 & 135 \\
& Pooled & 15.01 & 14.84 & 0.00 & 95.40 & 15.78 & 205 \\
\hline
\end{tabular}

On average, linked subsidiaries have higher corporate income tax burden per unit of assets than other subsidiaries. In this context, it is important to note that in 79 observations $\mathrm{TpA}$ ratio was $0 \%$ due to current corporate income tax expense equal to zero. In addition, 165 observations had TpA between $0 \%$ and $1 \%$.

ETR was, on average, higher in linked subsidiaries. Exceptionally high extreme values can signal extreme book-tax differences in Serbian subsidiaries. Furthermore, 41 observations had ETR of $0 \%$ due to zero current corporate income tax expense despite the achieved pre-tax profit. ETR was below statutory tax rate of $15 \%$ in 105 observations. On the other hand, seven observations had higher ETR than 50\%, while two highest ETRs $(95.40 \%$ and $87.73 \%)$ refer to other subsidiaries. 


\section{Statistical Tests}

Exceptionally high extreme values, as well as the lack of normal distribution of employed variables (according to Jarque-Bera test results), suggest using non-parametric statistical tests. The results of tests of differences in employed variables between linked and other subsidiaries are presented in Table 3. Although not tabulated, it is worth noting that these results do not differ substantially if parametric t-tests are employed.

Table 3 Statistical tests outcomes

\begin{tabular}{lcccc}
\hline \multirow{2}{*}{ Variable } & \multicolumn{2}{c}{ Observations } & \multicolumn{2}{c}{$\begin{array}{c}\text { Wilcoxon/Mann-Whitney } \\
\text { (tie-adj.) Method }\end{array}$} \\
\cline { 2 - 5 } & $\begin{array}{c}\text { Linked } \\
\text { subsidiaries }\end{array}$ & $\begin{array}{c}\text { Other } \\
\text { subsidiaries }\end{array}$ & Test value & p-value \\
\hline ROA & 84 & 167 & 1.019788 & 0.3078 \\
DR & 84 & 167 & 0.234911 & 0.8143 \\
LDR & 84 & 167 & 0.623890 & 0.5327 \\
TpA & 84 & 167 & 2.688904 & ${ }^{* * *} 0.0072$ \\
ETR & 70 & 135 & 1.788571 & 0.0737 \\
\hline \multicolumn{2}{c}{ Note: statistically significant at the $1 \%(* * *), 5 \%(* *)$ and $10 \%(*)$ level. }
\end{tabular}

Linked subsidiaries have higher median ROA, which is contrary to the logic of profit shifting to tax havens, and higher median DR ratio than other subsidiaries, which supports the theory about profit shifting to tax havens. However, differences in these variables between linked and other subsidiaries are not statistically significant. In addition, there is no significant difference between linked and other subsidiaries in terms of LDR.

Contrary to the profit shifting logic, it appears that linked subsidiaries have higher corporate income tax burden (both per unit of assets and unit of pre-tax profit) than other subsidiaries. Namely, linked subsidiaries have both a higher TpA and ETR than other subsidiaries with the differences being statistically significant. To check the sensitivity of the obtained research results to the implemented methodology, I also run the regression analysis.

\section{Regression Analysis}

The main variable of interest in the regression analysis is Tax_Haven. This variable has the value of 0 if the observation is other subsidiary and 1 if the observation is a linked subsidiary. I use ROA, DR, LDR, TpA and ETR (as defined earlier) as dependent variables. I also used natural logarithm of total assets (Ln_Assets) to control for variability of firm size among observations.

Table 4 presents random-effects regression analysis estimates. Breusch-Pagan LM test results showed that random-effects regression should be employed over ordinary least squares estimates. On the other hand, I 
could not run fixed-effects regression due to the near singular matrix problem as research model employs a time-invariant variable (Tax_Haven).

Table 4 Regression analysis estimates

\begin{tabular}{lrrrrr}
\hline & \multicolumn{5}{c}{ Dependent variable } \\
\cline { 2 - 6 } & \multicolumn{1}{c}{ ROA } & \multicolumn{1}{c}{ DR } & \multicolumn{1}{c}{ LDR } & \multicolumn{1}{c}{ TpA } & \multicolumn{1}{c}{ ETR } \\
\hline Constant & ${ }^{*} 20.6634$ & -18.7480 & ${ }^{* * *}-86.5062$ & $* * * 4.5529$ & ${ }^{* * *} 76.8415$ \\
& $(1.7821)$ & $(-0.6699)$ & $(-4.1266)$ & $(2.8878)$ & $(3.9334)$ \\
Tax_Haven & 2.9717 & -6.5141 & -3.3826 & ${ }^{* * *} 0.7510$ & $* 5.7446$ \\
& $(1.4770)$ & $(-1.0375)$ & $(-0.8510)$ & $(2.6547)$ & $(1.7828)$ \\
Ln_Assets & -1.2353 & ${ }^{* * * *} 5.6629$ & ${ }^{* * *} 7.0869$ & ${ }^{* *}-0.2771$ & ${ }^{* * * *}-4.6971$ \\
& $(-1.4911)$ & $(2.8384)$ & $(4.7326)$ & $(-2.4598)$ & $(-3.3506)$ \\
Year dummies & Yes & Yes & Yes & Yes & Yes \\
Adjusted R ${ }^{2}$ & 0.0230 & 0.0540 & 0.0723 & 0.0251 & 0.0375 \\
F-value & ${ }^{*} 2.1744$ & ${ }^{* * * *} 3.8556$ & $* * 4.8976$ & ${ }^{* *} 2.2883$ & $* * 2.5912$ \\
Observations & 251 & 251 & 251 & 251 & 205 \\
\hline
\end{tabular}

Note: beta coefficients in front of parentheses, t-statistics in parentheses; statistically significant at the $1 \%\left({ }^{* * *}\right), 5 \%\left({ }^{* *}\right)$ and $10 \%\left(^{*}\right)$ level.

Generally, regression estimates are quite consistent with statistical tests outcomes. The results of the regression analysis do not support the theory about profit shifting to tax havens either. Similar to the statistical tests outcomes, regression analysis shows that linked subsidiaries have significantly higher corporate income tax burden than other subsidiaries as they have both significantly higher TpA and ETR.

Therefore, statistical analysis shows that linked subsidiaries, in general, do not shift profit to tax havens to a greater extent than other subsidiaries. Relatively low statutory tax rate and many tax incentives available for further reduction of effective tax rate can discourage profit shifting to tax havens. It is interesting to point out the opinion of Gravelle (2009), who argues that any country with relatively low tax burden can be considered as a tax haven and emphasizes many Eastern European countries with statutory tax rates lower than $20 \%$ as examples. Serbia, with statutory tax rate of $15 \%$, clearly falls into this category, so it is possible that management of MNCs perceive Serbia as a country with a preferential tax regime.

One of the obstacles to profit shifting out from Serbia lies in the fact that Serbia imposes withholding tax payment on transfers to the Netherlands, Switzerland and Cyprus despite having signed double taxation treaties with these countries. However, the tax rates on these payments are lower than the tax rates prescribed by Corporate Profit Tax Law (The Official Gazette of the RS, no. 113/2017). In the line with this legal act, withholding tax rate is $20 \%$, or $25 \%$ if money recipient is a resident of a tax haven according to the list of tax havens from the Rulebook on the list of jurisdictions with preferential tax system (The Official Gazette of the 
RS, no. 122/12). On the other hand, according to the signed double taxation treaties, interest payment to Dutch residents is not taxed, while royalty payment is taxed at $10 \%$ withholding tax rate. Interest payment to Swiss residents is taxed at $10 \%$ withholding tax rate, while royalty payment is not taxed until Switzerland imposes withholding tax on royalty payments. Interest and royalty payments to Cypriot residents are taxed at $10 \%$ withholding tax rate.

The treatment of the Netherlands, Switzerland and Cyprus as tax havens can be furtherly discussed. In fact, Weyzig (2013) argues that the Netherlands is the leading conduit country (rather than traditional tax haven) in the world serving as a transit in the profit shifting pattern. Garcia-Bernardo, Fichtner, Takes \& Heemskerk (2017) add that both the Netherlands and Switzerland should be considered as conduit countries and confirm Cyprus as a tax haven.

I have also checked the robustness of the obtained results. In fact, many MNCs are de facto originally founded in countries that can be considered as tax havens. Therefore, the subsidiary's link with the tax haven entity is not always due to tax minimization motives but due to the fact that the parent company is originally founded in a tax haven. Thus, in the sample, at least six linked subsidiaries whose parent companies are founded in the Netherlands or Switzerland can be found. These subsidiaries should then be treated as other subsidiaries. In this case, the research sample would comprise 19 linked and 56 other subsidiaries. The results of such a robust analysis are quite similar to the original research results. In other words, the difference in profit shifting to tax havens between linked and other subsidiaries has been found neither with statistical tests outcomes nor regression analysis estimates. The results of the robustness analysis are not tabulated due length-limitations of this paper.

\section{CONCLUSION}

The empirical research in this paper studied profit shifting to European tax havens of 75 Serbian subsidiaries of MNCs between 2013 and 2016. In the paper, I examined differences in profit shifting between linked (directly owned by tax haven entity) and other (not directly owned by tax haven entity) subsidiaries. For these purposes, I have employed the following variables: return on assets (ROA), debt ratio (DR), long-term debt ratio (LDR), tax per unit of assets (TpA) and effective tax rate (ETR).

The research results suggest that the presence of a tax haven entity in the ownership structure of a subsidiary is not an important determinant of the employed variables. The linked subsidiaries of MNCs have higher median ROA and median DR, while median LDR is the same for linked and other subsidiaries. However, using non-parametric statistical tests and random-effects regression analysis, I have not found a statistically significant difference in ROA, DR and LDR between linked and other subsidiaries. I 
have also found that linked subsidiaries even have statistically significantly higher TpA and ETR than other subsidiaries. This finding indicates that linked subsidiaries have significantly higher corporate tax burden per unit of total assets and per unit of pre-tax profit.

Unlike previous research that employed similar variables (Fuest, \& Riedel, 2012; Jansky, \& Kokes, 2015; Jansky, \& Prats, 2015; Jansky, \& Kokes, 2016), I have not found significant difference in any employed variable between linked and other subsidiaries. It is necessary to bear in mind that statutory tax rate in Serbia is lower than statutory tax rates in countries captured by previous research. In general, it seems that the management of MNCs treats Serbia (and potentially other transition economies with relatively low statutory tax rates) as a substitute for traditional tax havens.

I believe that the research results may be useful to many interest groups. First of all, the management of MNCs should recognize that they may use low-tax transition economies instead of traditional tax havens when arranging tax-motivated related-party transactions. Such practice would help MNCs to avoid public scrutiny that is inherent to the usage of traditional tax havens. Second of all, when looking for typical profit shifting patterns, national tax authorities should recognize that the existence of a tax haven entity in the ownership structure of the subsidiary of MNC is not a red flag for its potential profit shifting activity.

The presented research results should be studied in the light of certain limitations. It should be noted that the classification of linked and other subsidiaries is based only on the direct ownership structure. The potential pyramidal ownership is not considered due to the lack of data. It is possible that among other subsidiaries, there exists a pyramidal tax haven ownership. For example, the other subsidiary can be directly owned by a German entity, whereas the German entity is owned by tax haven entity. In such situations, the tax haven entity is de facto the indirect owner of the other subsidiary.

It is also important to note that profit shifting to tax havens can be done by other subsidiaries as well, not only by linked subsidiaries. More specifically, the widely known limitations about sampling methodology can be attributed to this paper. It is also possible that the research results would differ if other than Oxfam (2016) list of tax havens is preferred or if other variables have been employed.

On the other hand, additional research is needed. For the purposes of a more detailed analysis, detailed information about subsidiaries operations is needed with special focus on related-party transactions. National tax authorities should insist on public disclosure of company tax reports in order to make additional information publicly accessible. Future research should include neighboring countries to compare the obtained results and should also include the subsample of domestic companies as a control subsample. 


\section{REFERENCES}

Arel-Bundock, V. (2017). The Unintended Consequences of Bilateralism: Treaty Shopping and International Tax Policy. International Organization, 71(2), 349-371. doi: 10.1017/S0020818317000108

Beer, S., \& Loeprick, J. (2015). Profit Shifting: Drivers of Transfer (Mis)Pricing and the Potential of Countermeasures. International Tax and Public Finance, 22(3), 426-451. doi: 10.1007/s10797-014-9323-2

Beuselinck, C., Deloof, M., \& Vanstraelen, A. (2015). Cross-Jurisdictional Income Shifting and Tax Enforcement: Evidence from Public versus Private Multinationals. Review of Accounting Studies, 20(2), 710-746. doi: 10.1007/ s11142-014-9310-y

Buettner, T., \& Wamser, G. (2013). Internal Debt and Multinational Profit Shifting: Empirical Evidence from Firm-level Panel Data. National Tax Journal, 66(1), 63-96. doi: 10.17310/ntj.2013.1.03

Chowdhry, B., \& Coval, J. (1998). Internal Financing of Multinational Subsidiaries: Debt vs. Equity. Journal of Corporate Finance, 4(1), 87-106. doi: 10.1016/S09291199(97)00011-4

Christian, C., \& Schultz, T. (2005). ROA-Based Estimates of Income Shifting by U.S. Multinational Corporations. In J. Dalton \& B. Kilss (Eds.), Recent Research on Tax Administration and Compliance (pp. 57-72). Washington, DC: Internal Revenue Service.

Clausing, K. (2003). Tax-Motivated Transfer Pricing and US Intrafirm Trade Prices. Journal of Public Economics, 87(9-10), 2207-2223. doi: 10.1016/S00472727(02)00015-4

Contractor, F. (2016). Tax Avoidance by Multinational Companies: Methods, Policies, and Ethics. Rutgers Business Review, 1(1), 27-43.

Corporate Profit Tax Law, The Official Gazette of the RS, no. 113 (2017)

Crivelli, E., de Mooij, R., \& Keen, M. (2016). Base Erosion, Profit Shifting and Developing Countries. FinanzArchiv: Public Finance Analysis, 72(3), 268301. doi: 10.1628/001522116X14646834385460

Dharmapala, D. (2014). What Do We Know about Base Erosion and Profit Shifting? A Review of the Empirical Literature. Fiscal Studies, 35(4), 421-448. doi: 10.1111/j.1475-5890.2014.12037.x

Dischinger, M., Knoll, B., \& Riedel, N. (2014). The Role of Headquarters in Multinational Profit Shifting Strategies. International Tax and Public Finance, 21(2), 248-271. doi: 10.1007/s10797-012-9265-5

Doupnik, T., \& Perera, H. (2012). International Accounting, $3^{\text {rd }}$ edition. New York, NY: McGraw-Hill.

Errico, L., \& Musalem, A. (1999). Offshore Banking: An Analysis of Micro- and MacroPrudential Issues, IMF Working Papers, WP/99/5. doi: 10.5089/9781451842166. 001

Faulkender, M., \& Smith, J. (2016). Taxes and Leverage at Multinational Corporations. Journal of Financial Economics, 122(1), 1-20. doi: 10.1016/j.jfineco.2016.05.011

Fuest, C., \& Riedel, N. (2012). Tax Evasion and Tax Avoidance: The Role of International Profit Shifting. In P. Reuter (Ed.), Draining Development? Controlling Flows of Illicit Funds from Developing Countries (pp. 109-141). Washington, DC: The World Bank. doi: 10.1596/978-0-8213-8869-3

Garcia-Bernardo, J., Fichtner, J., Takes, F., \& Heemskerk, E. (2017). Uncovering Offshore Financial Centers: Conduits and Sinks in the Global Corporate Ownership Network. Scientific Reports, 7(1), 1-10. doi: 10.1038/s41598-017-06322-9

Gravelle, J. (2009). Tax Havens: International Tax Avoidance and Evasion. National Tax Journal, 62(4), 727-753. doi: 10.17310/ntj.2009.4.07 
Grubert, H., \& Mutti, J. (1991). Taxes, Tariffs and Transfer Pricing in Multinational Corporate Decision Making. The Review of Economics and Statistics, 73(2), 285-293. doi: 10.2307/2109519

Hampton, M., \& Christensen, J. (2002). Offshore Pariahs? Small Island Economies, Tax Havens, and the Re-configuration of Global Finance. World Development, 30(9), 1657-1673. doi: 10.1016/S0305-750X(02)00054-2

Hanlon, M., \& Heitzman, S. (2010). A Review of Tax Research. Journal of Accounting and Economics, 50(2-3), 127-178. doi: 10.1016/j.jacceco.2010.09.002

Hines, J. (2010). Treasure Islands. Journal of Economic Perspectives, 24(4), 103-126. doi: $10.1257 /$ jep.24.4.103

Hines, J., \& Rice, E. (1994). Fiscal Paradise: Foreign Tax Havens and American Business. The Quarterly Journal of Economics, 109(1), 149-182. doi: 10.2307/2118431

Huizinga, H., \& Laeven, L. (2008). International Profit Shifting within Multinationals: A Multi-country Perspective. Journal of Public Economics, 92(5-6), 1164-1182. doi: 10.1016/j.jpubeco.2007.11.002

Huizinga, H., Laeven, L., \& Nicodeme, G. (2008). Capital Structure and International Debt Shifting. Journal of Financial Economics, 88(1), 80-118. doi: 10.1016/j.jfineco. 2007.05.006

Jansky, P., \& Kokes, O. (2015). Corporate Tax Base Erosion and Profit Shifting out of the Czech Republic. Post-Communist Economies, 27(4), 537-546. doi: 10.1080/14631377.2015.1084733

Jansky, P., \& Kokes, O. (2016). Profit-shifting from Czech Multinational Companies to European Tax Havens. Applied Economics Letters, 23(16), 1-4. doi: 10.1080/13504851.2015.1137543

Jansky, P., \& Prats, A. (2015). International Profit Shifting out of Developing Countries and the Role of Tax Havens. Development Policy Review, 33(3), 271-292. doi: $10.1111 /$ dpr.12113

Khouri, S., Elexa, L., Istok, M., \& Rosova, A. (2019). A Study from Slovakia on the Transfer of Slovak Companies to Tax Havens and Their Impact on the Sustainability of the Status of a Business Entity. Sustainability, 11(10), 1-18. doi: $10.3390 /$ su11102803

Kurdle, R. (2009). Did Blacklisting Hurt the Tax Havens? Journal of Money Laundering Control, 12(1), 33-49. doi: 10.1108/13685200910922633

Lennox, C., Lisowsky, P., \& Pittman, J. (2013). Tax Aggressiveness and Accounting Fraud. Journal of Accounting Research, 51(4), 739-778. doi: 10.1111/joar.12002

Loretz, S., \& Mokkas, S. (2015). Evidence for Profit Shifting with Tax-Sensitive Capital Stocks. FinanzArchiv: Public Finance Analysis, 71(1), 1-36. doi: 10.1628/001522115X14206439673251

Mittoo, U., \& Zhang, Z. (2008). The Capital Structure of Multinational Corporations: Canadian versus U.S. Evidence. Journal of Corporate Finance, 14(5), 706720. doi: 10.1016/j.jcorpfin.2008.09.012

OECD (2000). Towards Global Tax Cooperation: Progress in Identifying and Eliminating Harmful Tax Practices. Paris, France: OECD. doi: 10.1787/9789264184541-en

Oxfam (2016). Four EU Countries among World's Worst Corporate Tax Havens, New Report Reveals. Retrieved July 15, 2020. from www.oxfam.org/en/press-releases/ four-eu-countries-among-worlds-worst-corporate-tax-havens-new-report-reveals.

Rulebook on the list of jurisdictions with preferential tax system, The Official Gazette of the RS, no. 122 (2012)

Schwarz, P. (2009). Tax-Avoidance Strategies of American Multinationals: An Empirical Analysis. Managerial and Decision Economics, 30(8), 539-549. doi: $10.1002 /$ mde. 1471 
Weichenrieder, A. (2009). Profit Shifting in the EU: Evidence from Germany. International Tax and Public Finance, 16(3), 281-297. doi: 10.1007/s10797008-9068-x

Weyzig, F. (2013). Tax Treaty Shopping: Structural Determinants of Foreign Direct Investment Routed Through the Netherlands. International Tax and Public Finance, 20(6), 910-937. doi: 10.1007/s10797-012-9250-z

\title{
ПРЕМЕШТАЫЕ ДОБИТКА У ЕВРОПСКЕ ПОРЕСКЕ РАЈЕВЕ: СЛУЧАЈ ФИЛИЈАЛА МУЛТИНАЦИОНАЛНИХ КОМПАНИЈА У СРБИЈИ
}

\author{
Стефан Вржина \\ Универзитет у Крагујевцу, Економски факултет, Крагјевац, Република Србија
}

\section{Резиме}

Упркос чињеници да се премештање добитка мултинационалних компанија (МНК) у пореске рајеве изучава деценијама, овакве праксе су и даље недовољно јасно подручје пословања МНК. Захваљујући чињеници да послују у великом броју земаља, МНК имају могућност да добитак остварен у држави са вишим пореским оптерећењем вештачки преместе у државе са нижим пореским оптерећењем. У раду је испитано како повезаност филијала МНК које послују у Србији са ентитетима у пореским рајевима утиче на њихово премештање добитка, односно да ли између филијала које су директно повезане са ентитетима у пореским рајевима и осталих филијала постоји значајна разлика у премештању добитка.

За сврхе истраживања је формиран узорак од 75 филијала МНК, при чему је анализиран период између 2013. и 2016. године, када је прописана стопа пореза на добитак у Србији била на константном нивоу од $15 \%$. Премештање добитка филијала МНК у Србији испитано је коришћењем следећих индикатора: однос добитка пре опорезивања и укупне имовине, однос укупних обавеза и укупне имовине, однос дугорочних обавеза и укупне имовине, однос текућег расхода за порез на добитак и укупне имовине, и однос текућег расхода за порез на добитак и добитка пре опорезивања.

Резултати истраживања су показали да филијале које су директно повезане са ентитетима у пореским рајевима не врше интензивније премештање добитка у пореске рајеве у односу на остале филијале. Овакав закључак је последица чињенице да непараметарски статистички тестови и панел-регресиона анализа нису пронашли значајну разлику у посматраним индикаторима између две поменуте групе филијала. У раду је закључено да филијале МНК немају великог мотива за премештање добитка оствареног у Србији у пореске рајеве, имајући у виду релативно ниску прописану и ефективну стопу пореза на добитак. Стога, могуће је да менаџмент МНК посматра Србију као државу са преференцијалним пореским режимом. Додатно, плаћање пореза по одбитку (упркос потписаним уговорима о избегавању двоструког опорезивања) може демотивисати премештање добитка из Србије. У закључку рада је истакнута потреба да националне пореске власти инсистирају на јавном објављивању пореских извештаја МНК како би њихове пореске праксе постале транспарентније. 